\title{
Taxing as Income the Receipt of Interest-Free Loans†
}

The current tax treatment of loans made at less than fair market value accords different consequences to two substantially similar transactions. If a home, an automobile, or equipment is loaned or sold at less than its fair market price, the difference between the value of the transferred property and the price paid for it is deemed taxable income to the recipient unless he can show that a gift was intended. If, on the other hand, money is loaned at less than its fair market price, courts attach no tax consequences to the loan. Not until 1961 did the Commissioner of Internal Revenue argue that an interest-free loan of money constituted a taxable economic benefit, and even then the Tax Court rejected this contention and held that an interest-free loan of money does not give rise to gross income. ${ }^{1}$

The primary vehicle for taxing economic benefits has been section 61 (a) of the Internal Revenue Code of $1954 .^{2}$ Under this section both loans and sales of property to employees or shareholders at less than fair market price have been held to create income taxable as compensation or corporate dividends respectively. This comment suggests that section 61 (a) be utilized to tax the economic benefit from interest-free loans of money.

\section{Gross Income From Bargain Transfers}

In J. Simpson Dean ${ }^{3}$ the Commissioner argued for the first time that when a corporation loans money to a shareholder without charging interest a taxable economic benefit is conferred on that shareholder. Within a two year period Dean and his wife had borrowed without interest over $\$ 2,000,000$ from the Nemours Corporation, of which they were virtually the sole stockholders. The Commissioner sought to increase the Deans' taxable income by the amount of money they would have been required to pay in order to borrow $\$ 2,000,000$ in an arm's-

$\dagger$ Bernard A. Schlifke, J.D. 1965, The University of Chicago Law School.

1 J. Simpson Dean, 35 T.C. 1083 (1961).

2 "Except as otherwise provided in this subtitle, gross income means all income from whatever source derived ...." INT. REv. CODE OF 1954, § 61(a).

335 T.C. 1083 (1961). 
length transaction. ${ }^{4}$ To support this position the Commissioner relied on a series of cases holding that the rent-free use of corporate property constitutes a taxable economic benefit to the user. ${ }^{5}$

The Tax Court rejected this analogy on the ground that had the petitioners borrowed the money at interest, the interest payments would have been deductible and this deduction offset against the imputed income would result in no tax. ${ }^{6}$ The court also argued that since interest-free loans result in neither an interest deduction for the borrower ${ }^{7}$ nor interest income to the lender, ${ }^{8}$ there should be no taxable gain to the borrower. ${ }^{9}$

Both the concurring and dissenting opinions took issue with the majority's broad generalizations. The concurring judges agreed that the interest-free loan did not result in an increase in petitioner's tax; they reasoned that if the petitioners borrowed the money at interest, the increase in their gross income would probably be offset by a corresponding interest deduction. However, they recognized the possibility that the interest would not be deductible under section 163(a) if, for example, the money had been used to purchase tax-exempt se-

4 The Commissioner based his hopes that the Tax Court would accept this argument on the court's statement in Paulina DuPont Dean, 19 CCH Tax Ct. Mem. 281 (1960), a related case involving the same parties in which the issue was the value of Nemours Corporation stock for gift tax purposes. These outstanding loans to the Deans were one factor considered in arriving at a valuation. The court stated: "Viewed realistically, the lending of over two million dollars to petitioners without interest might be looked upon as a means of passing on earnings (certainly potential earning) of Nemours in lieu of dividends, to the extent of a reasonable interest on such loans . ..." Id. at 288. However, the Tax Court in J. Simpson Dean rejected this statement as being mere dictum unsupported by authority. 35 T.C. at 1089.

5 Rent-free use of corporation's house: Dean v. Commissioner, 187 F.2d 1019 (3d Cir. 1951); Paulina DuPont Dean, 9 T.C. 256 (1947); Reynard Corp., 30 B.T.A. 451 (1934). Rent-free use of corporation's apartment: Chandler v. Commissioner, 119 F.2d 623 (3d Cir. 1941); Charles A. Frueauff, 30 B.T.A. 449 (1934). Personal use of corporation's automobile: Bardahl Mfg. Co., 19 CCH Tax Ct. Mem. 1245 (1960); Sam Rosania, 15 CCH Tax Ct. Mem. 580 (1956); Rodgers Dairy Co., I4 T.C. 66 (1950). Personal use of corporation's boat: Challenge Mfg. Co., 37 T.C. 650 (1962).

635 T.C. at 1090.

7 Ibid., citing Howell Turpentine Co., 6 T.C. 364 (1946), rev'd on other grounds, 162 F.2d 316 (5th Cir. 1947); Rainbow Gasoline Corp., 31 B.T.A. 1050 (1935); A. Backus, Jr., \& Sons, 6 B.T.A. 590 (1927), all upholding the Commissioner's denial of an interest paid deduction because the borrower failed to show a legal obligation to pay interest, even though in Howell interest was in fact paid.

835 T.C. at 1090, citing Brandtjen \& Kluge, Inc., 34 T.C. 416 (1960); Society Brand Clothes, Inc., 18 T.C. 304 (1952); Combs Lumber Co., 41 B.T.A. 339 (1940). In each case it was shown that no interest was paid and that the parties intended the loans to be interest-free. In none of the cases cited herein or in note 7 supra did the Commissioner raise the arguments made in the Dean case.

o 35 T.C. at 1090. 
curities. ${ }^{10}$ Still, even the concurring judges failed to recognize that section 163(a) allows a deduction only for interest "paid or accrued ... on indebtedness."11 Because the borrower of an interest-free loan is not obligated to pay any interest, it would seem clear that no deduction is available under section 163(a).

The dissent went further and agreed wholeheartedly with the Commissioner that this case was the same for tax purposes as those which hold that a taxable economic benefit arises from the free use of corporate property, saying that " 'interest' in the sense that it represents compensation paid for the use, forbearance, or detention of money, may be likened to 'rent' which is paid for the use of property.' 12 The dissent concluded that the taxpayers should have been required to prove that interest on these loans, had they paid it, would have been fully deductible.

The approach of the Tax Court in Dean appears to be inconsistent with earlier cases defining the scope of section $61(a) .{ }^{13}$ In Reynard Corp..$^{14}$ the taxpayer, Reynard's president and sole stockholder, resided in a house owned by the corporation but paid no rent. The Board of Tax Appeals held the rental value of the house to be taxable compensation. ${ }^{15}$ Cases since Reynard have held that the rent-free use of a

10 INT. REV. CODE of 1954, $\$ 163(d)(2)$, set out in note 17 infra.

11 This language has been interpreted to mean that interest paid or accrued is deductible only when it arises pursuant to an enforceable obligation to pay a principal sum and to pay interest thereon. Lewis E. Christensen, 40 T.C. 563 (1963); John G. Sellers, 22 CGH Tax Ct. Mem. 1327 (1963); D. Loveman \& Son Export Corp., 34 T.C. 776 (1960); First Nat'l Co., 32 T.C. 798 (1959); Charles L. Huisking \& Co., 4 T.C. 595 (1945). See also, 4 Mertens, The Law of Federal Income Taxation \& 26.04 (Zimet rev. 1960). A borrower might argue that since income is imputed to him, he should be permitted an imputed interest paid deduction to offset against imputed income. But income is imputed because the taxpayer in fact received an economic benefit; no interest deduction should be imputed because he did not in fact incur an obligation to pay interest.

1235 T.C. at 1091.

13 Treas. Reg. $\$ 1.61-1$ (a) (1953) asserts that gross income includes "income realized in any form, whether in money, property, or services." The courts have recognized that Congress intended a very broad interpretation of "gross income": "We have repeatedly held that in defining 'gross income' as broadly as it did in $\$ 22$ (a) Congress intended to tax all gains except those specifically exempted." Commissioner v. LoBue, 351 U.S. 243, 246 (1956). Section 61 of the 1954 Code is derived from $\S 22$ of the 1939 Code, but although $\S 61$ (a) is more concise than $\S 22(a)$, there is no indication of any intent to narrow the scope of $\S 22($ a). Commissioner v. Glenshaw Glass Co., 348 U.S. 426, 432 (1955).

1430 B.T.A. 451 (1934).

15 The Board also concluded that the corporation was entitled to a deduction for depreciation since the residence had been used for the business of compensating an employee. In a subsequent and related case, Reynard Corp., 37 B.T.A. 552 (1938), the Board indicated that a deduction for compensation paid should be denied because the rental value of the residence had not been added to the corporation's income. The effect of the two Reynard cases upon employers is that when an employee is given the use of an 
residence, an automobile, or a boat results in income to the user. ${ }^{16}$ It would seem that both interest paid for the use of money and rent paid for the use of tangible property represent the price paid for the use of property. If section 61(a) requires the inclusion in gross income of the difference between the rent paid and the rental value of tangible property, it should also require the inclusion in income of the difference between interest paid and the interest rate for the use of money.

The majority in Dean dismissed this argument with the observation that if interest were imputed to the borrower, an offsetting interest-paid deduction would also have to be imputed. This conclusion is unsatisfactory for several reasons. First, even though interest payments on borrowed funds will usually be tax deductible, one who borrows without an obligation to pay interest will benefit economically unless he is in a $100 \%$ tax bracket. For example, a taxpayer in a $50 \%$ tax bracket who can deduct a $\$ 1000$ interest expense saves $\$ 500$ in taxes but is still $\$ 500$ out-of-pocket. This fact seems to have eluded the court. Instead of placing the recipient of an interest-free loan in a tax position comparable to one who did pay interest, as it apparently intended to do, the court accentuated the difference by permitting the economic benefit from the interest-free loan to be received free of tax. Second, even if a tax washout were the necessary result, the addition and the deduction should have been reflected in the tax return to maintain the basic structure of our tax system which involves setting out gross income and then listing deductions therefrom. Finally, it is by no means clear that a tax washout was the necessary result. The court ignored the exceptions to section 163(a) listed in section $163(\mathrm{~d})(\mathrm{I})-(4)^{17}$

asset as part of his compensation, the employer may deduct as compensation paid only the cost to him of permitting the employee to use the asset involved. In addition to actual outlays such as utility bills for a house or maintenance expenses for an auto, the measure of this cost is depreciation, which at least in theory represents the decrease in the asset's value during the period of use.

16 See note 5 supra. In 1946 the Internal Revenue Service announced that, respecting all transfers of property by a corporation to a shareholder or by an employer to an employee at less than the fair market price, the transferee would be taxed on the difference between the amount he paid for the property and its fair market value, his basis for the property being the amount he paid plus the gain recognized on the transfer. T.D. 5507, 1946-1 Cum. Bull. 18. This policy was applied to encompass a corporation's leasing an apartment to a stockholder at less than the fair rental value. The difference between the rent paid and the fair rental value was taxed to the shareholder as a dividend from the corporation. Rev. Rul. 58-1, 1958-1 CuM. BuLl. 173.

17 "(1) For disallowance of certain amounts paid in connection with insurance, endowment, or annuity contracts, see section 264 .

(2) For disallowance of deduction for interest relating to tax-exempt income, see section 265(2).

(3) For disallowance of deduction for carrying charges chargeable to capital account, see section 266. 
and the possibility that section 163(a) was inapplicable altogether because there was no obligation to pay interest and because in fact no interest was "paid or accrued." 18 Thus, by permitting the taxpayers in Dean to receive an economic benefit completely free of tax, the court sanctioned a tax loophole which discriminates against interest-free loans of all other property and which is not supported by logic or statutory language. ${ }^{19}$

The view that no income is created by an interest-free loan has greatly influenced the taxation of split-dollar life insurance. Basically, split-dollar life insurance is a means of providing term insurance at a very low cost to the insured. Under a typical plan the life of an employee is insured by his employer who pays the premium to the extent of the yearly increase in the policy's cash surrender value. The difference between the annual premium and the yearly increase in the cash surrender value is paid by the insured employee. The money advanced by the employer is secured by the cash value of the policy. Should the insured die while the policy is in effect, the employer is paid the cash value of the policy with the remainder of the proceeds going to the beneficiary named by the insured. ${ }^{20}$ Revenue Ruling $55-713^{21}$ determined that split-dollar insurance plans were essentially interest-free loans, usually from an employer to an employee, secured by the cash surrender value of a life insurance policy which the employee purchased with the proceeds of the loan. Consequently, no income was imputed to the employee since he merely received a loan of money, and the employer was denied an expense deduction since he merely loaned money that would eventually be repaid.

The tax advantages created by this analysis of split-dollar insurance were short-lived.22 Revenue Ruling 64-328 concluded that split-dol-

(4) For disallowance of interest with respect to transactions between related taxpayers, see section 267." INT. REv. Code of 1954, §§ 163(d)(1)-(4).

18 See note 11 supra.

19 Although the Commissioner has not acquiesced in the Dean decision, it is the only authority expressly dealing with the taxation of an interest-free loan.

20 Hoxie, Tax Consequences of Traditional Split-Dollar Agreements and Their Variants, 16 J. AM. Soc'Y C.L.U. 197 (1962).

21 1955-2 Cum. Burc. 23.

22 The change in the treatment of split-dollar insurance was foreshadowed by a statement in the House and Senate Committee report on the Revenue Act of 1964. H.R. REP. No. 749, 88th Cong., Ist Sess. 62 (1962); S. REp. No. 830, 88th Cong., 2d Sess. 78 (1964). Rev. Rut. 64-328, 1964-2 Cum. Bull. 11, which reversed Rev. RuL. 55-713, 1955-2 CuM. BuLl. 23, included the following reference to these reports: "The proper tax treatment of such life insurance arrangements between employers and employees has been reconsidered in the light of the statements in the House and Senate Committee Reports pertaining to the Revenue Act of 1964 ... that legislation to provide the proper tax treatment of 'split dollar' life insurance arrangements had been deferred because it was 
lar insurance plans were not the same as interest-free loans. ${ }^{23}$ Instead, the employer is viewed as purchasing insurance protection for the employee with the earnings on funds he has invested in a life insurance contract. ${ }^{24}$ Under this analysis, the employee is taxed on the value of the free insurance protection he receives. Split-dollar insurance is thus classed with all other payments or loans in kind to an employee; income is imputed to the recipient on the theory that he has received an economic benefit. ${ }^{25}$

The tax treatment of split-dollar insurance highlights the tenuous distinction between interest-free loans of money and transfers of other property at less than fair market value. If an employer loans an employee money with which he purchases insurance protection for himself, the employee pays no tax. However, the employee is taxed on the value of the insurance protection he receives if his employer purchases the insurance directly with funds the employee has an obligation to repay his employer. The analysis in Revenue Ruling 55-713 probably is more in accord with the substance of the transaction than is the analysis in the later ruling; only because of an artificial distinction between loans of money and loans of other property was the Commissioner required to distort his conception of a transaction in order to tax an obviously taxable benefit. The taxation of split-dollar insurance, which is essentially an interest-free loan, ${ }^{26}$ bolsters the argument for taxing all forms of interest-free loans.

The suggestion that interest-free loans create a taxable economic benefit is particularly significant in light of newly proposed regulations ${ }^{27}$ for section $482 .{ }^{28}$ These will circumvent the judicially created

believed that 'the issues involved in this problem, and the proper solution, including the possibility of administrative action, are in need of further study by the Treasury Department.'" 1964-2 Cum. BuLL. at 13.

23 1964-2 CuM. Bull. 11.

24 " $[\mathrm{T}]$ he employer provides the funds representing the investment element in the life insurance contract, which would, in arm's-length dealings, entitle it to the earnings accruing to that element. The effect of the arrangement ... however, is that the earnings on the investment element in the contract are applied to provide current life insurance protection to the employee from year to year, without cost to the employee, to the extent that the earnings are sufficient to so do." Id. at 13.

25 The employer receives no deduction for the cost of the insurance protection his investment afforded the employee. Since the employer eventually recovers the entire amount he invested, the only cost to him is the income foregone on the sum invested. This is neither imputed to him as income nor deductible by him as an expense. See text accompanying notes $40-41$ infra.

26 See J. Simpson Dean, 35 T.C. 1083, 1090 n.3 (1961).

27 Proposed Treas. Reg. § 1.482-2, 30 Fed. Reg. 4257 (1965).

28 INT. REv. CODE OF 1954, $\$ 482$ : "In any case of two or more organizations, trades, or businesses (whether or not incorporated, whether or not organized in the United States, and whether or not affiliated) owned or controlled directly or indirectly by the same 
doctrine that section 482 does not empower the Commissioner to impute income to a taxpayer with respect to a transaction where none otherwise existed. ${ }^{29}$ This interpretation has heretofore precluded the use of section 482 to adjust income to reflect an arm's-length price when a loan or transfer between controlled business entities was made at a lower than market price. The proposed regulations consist of an amendment to Treasury Regulation section 1-482-1 and a new Regulation section 1-482-2 which provide in substance that if an adjustment is made under section 482 to the income of one member of a group of controlled taxpayers, the Commissioner must also make appropriate correlative adjustments to the income of other members of the group. The proposed regulations would allow the Commissioner to utilize the arm's-length price of the transferred property in computing gross income. Respecting loans or advances the Commissioner would be empowered to impute a charge equal to the difference between the price paid and an arm's-length price. If the proposed regulations are

interests, the Secretary or his delegate may distribute, apportion, or allocate gross income, deductions, credits, or allowances between or among such organizations, trades or businesses, if he determines that such distribution, apportionment or allocation is necessary in order to prevent evasion of taxes or clearly to reflect the income of any of such organizations, trades, or businesses."

Note that there are two built-in limitations on the use of $\S 482$. The tax entities must be organizations, trades, or businesses, whether corporate, individual, or partnership, and the operation of these entities must be controlled, either directly or indirectly, by the same interests. Thus, $\S 482$ cannot be invoked to reshape transactions between an employer and employee or between a corporation and its stockholders.

29 This doctrine stems primarily from the decisions in Tennessee-Arkansas Gravel Co. v. Commissioner, 112 F.2d 508 (6th Cir. 1940), and Smith-Bridgman \& Co., 16 T.C. 287 (1951). In Tennessee-Arkansas Gravel, a parent corporation loaned equipment to its subsidiary without charge. The Board of Tax Appeals sustained the Commissioner's addition of an imputed rental charge to the income of the parent corporation under the authority of $\S 482$ ( $\S 45$ of the 1939 Code). However, the court of appeals reversed the Board and stated: "[T] he Commissioner's authority extended no further than to 'distribute, apportion, or allocate gross income' between them .... Section 45, supra, did not authorize the Commissioner to set up income where none existed. The principal purpose of that section was to clearly reflect income that did exist." $112 \mathrm{~F} .2 \mathrm{~d}$ at 510 .

In Smith-Bridgman, it was argued that income was distorted when a subsidiary corporation loaned money at no interest to its parent corporation to enable the parent to redeem its outstanding debentures. The Commissioner purported to be "allocating" income (an amount equal to $4 \%$ of the outstanding loans) from the parent to the subsidiary "in order to prevent evasion of taxes and to clearly reflect income" under the authority of § 482. 16 T.C. at 293. The Tax Court, however, said the Commissioner had not "allocated" income since he made no adjustment to the income or deductions of the parent. "We think this record clearly establishes that the respondent has not distributed, apportioned, or allocated gross income but has created or attributed income where none in fact existed." Id. at 294-95. These decisions, and others to the same effect, have been the subject of sharp criticism. See Hewitt, Section 482-Allocation of Income and Deductions Among Related Taxpayers, N.Y.U. 20TH YNST. ON FED. TAX 463 (1962); Plumb \&: Kapp, Reallocation of Income and Deductions Under Section 482, 41 TAXEs 809 (1963). 
adopted and upheld by the courts, ${ }^{30}$ section 482 will be an effective weapon for taxing interest-free loans between controlled business entities. Furthermore, the proposals are another indication of the Commissioner's awareness that interest-free loans do confer a benefit on borrowers which should be subject to taxation.

\section{Proposals for Taxing Interest-Free Loans}

An accurate determination of the benefit to a borrower of not having to pay interest on a loan must reflect the tax saving that would result if interest paid were allowed as a deductible expense. ${ }^{31}$ The economic benefit from an interest-free loan consists of the interest the borrower is relieved from paying, less the tax saving that would have resulted if the funds had been borrowed at arm's-length and the interest thus paid had been deducted as an expense from the borrower's income. The resulting figure does not simply represent imputed interest; rather, it is an attempt to measure the actual economic benefit of not having to pay interest on a loan. For example, $A$ receives a $\$ 10,000$ interest-free loan from his employer and invests the money in a home for his family. Assume that $A$ is in a $25 \%$ tax bracket and that a bank would charge him $\$ 1,000$ interest the first year for a comparable loan. If he had borrowed the money from a bank, paid $\$ 1,000$ interest, and deducted the $\$ 1,000$ interest paid from his income, thereby reducing his tax by $\$ 250$, the net cost to him of the loan would have been $\$ 750$. The effect of the interest-free loan under these assumed facts is to give $A$ a salary increase of $\$ 750$ which would not be subject to taxation under present law. ${ }^{32}$ This net amount is the benefit toward which the following proposals for taxing interest-free loans are directed.

30 The doctrine upon which the proposed regulation is based will again be tested in the courts if a petition filed in the Tax Court by Kimberly-Clark Corporation reaches a trial on the merits. Docket No. 6063-64, T.C., Dec. 22, 1964. The petitioner is challenging additions to its income representing imputed royalties for the use of technical information and trade names, and imputed interest on loans to foreign subsidiaries.

31 While there are exceptions to $\$ 163$ (a) (see $\$ 163(\mathrm{~d})(1)-(4)$ ), in the vast majority of cases a tax deduction will result if interest is paid. But if the transaction does fall within one of the exceptions and an interest deduction could not have been taken, the value of the interest-free loan would simply be the interest which the borrower would have paid at arm's-length.

32 It might be argued that in fact there is no economic benefit here because the employee's taxable income would have remained constant had he received $\$ 1,000$ from his employer and then used this to pay the interest on money he borrowed from a bank, as opposed to receiving an interest-free loan from his employer as discussed in the example. However, that analogy is not appropriate because it consists of two independent and unrelated transactions. The receipt of a $\$ 1,000$ salary increase is a separate taxable event; the employee may or may not use it to pay the interest on a loan. Should the money be used to pay the interest on a loan, the employee would quite properly 
This gain may be taxed in several ways. One approach would subject the gain to the same tax consequences regardless of the uses to which the borrowed funds were put. This solution is based on two assumptions. The first is that an economic benefit is received whenever a person borrows something without a corresponding obligation to pay the market price for borrowing. Once the existence of an economic benefit is established, it will be taxed unless the loan was granted as a gift or inheritance or is otherwise excludable from gross income. The second assumption is that for tax purposes interest paid for the use of money should be treated the same as rent paid for the use of property in that the recipient of the benefit is taxed on its full value regardless of the use to which the property is put. Generally these assumptions are not difficult to make because in an arm's-length transaction interest would be charged regardless of the use to which the money was put; hence, the borrower receives an economic benefit whenever relieved from making this payment. Since the receipt of a benefit is what gives rise to taxable income, subsequent transactions are irrelevant in determining the tax treatment of that benefit.

The main weakness of this solution is that it results in double taxation where the borrower earns income by investing the borrowed funds. Taxing the borrower on the market value of the use of funds merely taxes him on the earning power of those funds, which is the measure of their value. If this potential earning power is harnessed and actually earns income which is taxed, two taxes are imposed: one on the potential income and one on the actual income. To illustrate, assume a loan which would command $\$ 1000$ interest if borrowed from a bank. Even if the borrower puts the money in a cookie jar, he is taxed on $\$ 1,000$, the value of the asset he has received, because he has received the wherewithal to earn $\$ 1000$. If he invests the proceeds in securities which earn $\$ 1000$, taxing those earnings as well as the receipt of the loan would clearly tax the same gain twice.

A second possible solution for the interest-free loan problem would be to measure the economic benefit from the free use of money by what was actually gained with its use. Under this analysis, rather than making an interest-free loan, the lender would be viewed as purchasing assets for the use or benefit of the borrower. If the borrowed funds were used to purchase a home, the rental value of the home would constitute the borrower's gain from the transaction. If the borrower merely salted the money away, although he might obtain some psychological benefit from

be allowed a deduction for interest paid. However, this comment deals with the situation where there is only one transaction, the interest-free loan. 
possessing the money, there would be no economic or taxable benefit. If he invested the funds, he might earn a profit or incur a loss: the value of the loan to him would not be determined until the investment were sold and the gain or loss realized.

The merits of this second proposal are most apparent when the lender requires that the borrowed funds be used only in certain specified ways. When funds are so restricted, the borrower's economic benefit can be said to derive not from the loan as such but from the particular use he may make of the proceeds of the loan. If borrowed funds must be invested in a manner stipulated by the lender, it seems unduly harsh to increase the income of the borrower by a supposed economic benefit even if the investment proves to be a failure and a loss is incurred. ${ }^{33}$ However, since this proposal would not tax an unrestricted loan which was not used productively, it conflicts with the general policy of taxing the recipient of an economic benefit whether or not he uses it. ${ }^{34}$

A third alternative would combine the two solutions discussed above: the borrower would be taxed on the interest-free use of the money, measured by the prime rate charged by banks during the period of the loan, ${ }^{35}$ plus the "net gain" from his use of the loan. ${ }^{36}$ "Net gain" here denotes the gain from the investment less the cost of the investment in terms of the interest that normally would have been paid for the use of the money. For example, if the funds were invested in a home, the employee's income would be increased by the amount of the economic benefit of the interest-free loan plus the amount by which the rental value of the home exceeds the imputed value of the loan. If the funds were not used, the employee's income would still be increased by the value of the loan. If the funds were invested in income producing property, the employee's income would be increased by the value of the loan

33 Such a situation is not hard to imagine. A corporation may lend its president money with which to purchase the company's stock, to strengthen his personal concern in the company's success. The company may not flourish, and the investment may decrease in value.

34 For example, Reynard Corp., 30 B.T.A. 451 (1934), which involved the rent-free use of a residence, held that the full yearly rental was income to the taxpayer even though he occupied the residence only six or seven months a year. "[T] he premises were his to occupy whenever he chose." Id. at 453.

35 In Dean the Commissioner computed the taxpayer's deficiency as the interest which would have been paid at the prime rate for the period of the loan. 35 T.C. at 1088. This method is adopted here. It is easy to apply and accurately reflects the realities of this particular situation if the borrower is a good credit risk for this lender.

30 This could be alternatively explained as taxing the borrower on whichever was greater, the gain from not having to pay interest or the income actually earned by the use of the funds. 
plus the amount by which the earnings from the investment ${ }^{37}$ exceeded the imputed value of the loan.

This third alternative appears to afford the most satisfactory results. The borrower is taxed on the amount of the interest he would have had to pay at arm's-length because this represents his gain from possessing the funds. If by investing the funds he converts this imputed gain into money, ${ }^{38}$ taxation of the money gain as well as the imputed gain would clearly constitute double taxation. The third approach avoids this harsh result. ${ }^{39}$

One other point deserves mention. If the recipient of an interest-free

37 Any attempt to determine the earnings from an investment of the funds presents problems. One question is whether these earnings should be measured solely by current earnings of the investment or also by changes in the investment's value. It is suggested that only the current taxable earnings be used as the measure of the earnings from the investment for purposes of taxing interest-free loans. Ordinarily a taxpayer is taxed on the current earnings from an investment and on realized capital increments. No justification appears for departing from that approach because an asset was purchased with money borrowed at no interest. Increments in the capital value of the asset will be reported as capital gains or losses when the asset is sold. This procedure conforms to the Code's distinction between ordinary and capital income and avoids the difficult task of determining capital gain income before the asset is sold.

38 One of the problems which the suggested proposal may raise is how to determine what uses were made of the borrowed funds. The problem might be met by placing the burden of keeping records of this matter on the taxpayer. This approach is suggested by the dissent in Dean, which stated that the Commissioner satisfies his burden of establishing a deficiency by showing the existence of an interest-free loan. Taxpayers then must "plead and establish that had they been required to pay interest on the loans in question they would have been entitled to deduct such interest from their gross income." 35 T.C. at 1092. Extending this attitude to the proposal suggested here, a presumption could be raised that none of the taxpayer's income during the period of the loan was attributable to the use of the loan; this could easily be rebutted by any evidence of the use to which the proceeds of the loan actually were put. The taxpayer will seek to attribute income to the loan to avoid double taxation of that income. He will be taxed on the value of the loan and all his other income unless he can show that some of this other income is attributable to the use of the loan. If he can identify the income attributable to the loan, however, he will be taxed only on the income not attributable to the loan plus the value of the loan and the "net gain" from it. See text accompanying notes 35-36 supra.

39 This proposal would not avoid the hardship of taxing one who received a restricted use loan on the full market value of the loan. Of course, such a borrower could always elect to refuse the loan. But a better solution might be to modify the proposal in the following way: if the borrower could prove that none of the uses to which he was permitted to put the loan could yield a return equal to the prime bank rate of interest, he would be taxed only on the value of the borrowed sum in the permissible use with the highest return. Thus, if the funds could only be invested in $2 \%$ municipal or $3 \%$ federal bonds, income of $3 \%$ of the loan would be imputed to the borrower whether or not he actually used the loan to purchase federal bonds. If the funds were restricted to use in real estate investment, the borrower would be unable to prove that the return on the proceeds could not possibly equal the prime bank rate, and he would be taxed as if the loan were unrestricted. 
loan is charged with income attributable to the economic benefit from that loan, symmetry seems to require that the lender be granted a deduction when the relationship between borrower and lender would ordinarily justify a deduction for payments made by the lender to the borrower. An employer, for example, could reasonably claim a deduction for compensation paid in the form of the free use of its money. However, deductions depend not on symmetry but upon specific provisions of the Internal Revenue Code. The mere fact that by lending its money the lender foregoes the earnings it might have received by using the money does not justify a deduction. The lender could argue that since an interest-free loan of money is really the same as the loan of other types of property, and since deductions are allowed the lender of other types of property, precedent supports his claim. However, in cases involving the loan of property at bargain rental charges, the measure of the deduction is cost. In both Reynard Corp. ${ }^{40}$ and Rodgers Dairy Co., ${ }^{41}$ cost consisted of the depreciation on the asset loaned and the money actually expended on the transaction. However, since for tax purposes the value of the dollar is presumed to remain constant, no depreciation may be taken on a sum of money. Hence, only out-of-pocket costs may be considered in determining the cost of loaning money at a bargain rate.

Ordinarily the only expenditure involved in making such a loan would be interest charges that the lender paid if he borrowed money in order to make the loan. Since interest payments generally are deductible under section 163(a), the lender can obtain a deduction for interest he actually paid without resort to a doctrine of imputed deductions. Therefore, calculating cost in the same manner as when other kinds of property are loaned, the lender will not be allowed a deduction directly related to his lending money at a bargain rate..$^{2}$

This third proposal for taxing interest-free loans would eliminate

4030 B.T.A. 451 (1934).

4114 T.C. $66(1950)$.

42 This conclusion is justified even though the lender may argue that because he has foregone income by lending his employee the funds he should be allowed a deduction. It is true that if instead of granting an employee the use of money without interest the employer had invested the money and distributed an amount equal to the earnings thereon to the employee, he would have had a tax washout, as there would be an addition to income representing the earnings on the investment and a deduction for compensation paid, both equal in amount. But that involves two distinct transactions with independent tax consequences, and the net result of those two transactions will not govern an interest-free loan, which involves only one transaction. See Reynard Corp., 37 B.T.A. 552 (1938), rejecting the corporation's claim of a deduction for compensation paid equal in amount to the rental value of the residence loaned without charge to the corporation's president. 
the unjustifiably favored tax status presently accorded loans of money at less than fair market value. At the same time it would avoid double taxation inherent in taxing the imputed income regardless of the use to which the loan is put and would assure full taxation of the benefit received. 